\title{
Application of taguchi experiment design to reduce lignin contents of rice straw
}

\author{
Selvia Aprilyantia ${ }^{*}$, Faizah Suryania ${ }^{a}$ Azharia \\ aDepartment of Industrial Engineering, Universitas Tridinanti, Palembang, Indonesia.
}

*Corresponding Author: selvia1704@univ-tridinanti.ac.id

ARTICLE INFO

\section{Keywords \\ Design; \\ Rice Straw; \\ Lignin; \\ Ozonolysis; \\ Taguchi.}

\section{Article history}

Received:

29 June, 2020

Revised:

20 July, 2020

Accepted:

5 August, 2020

Available online:

21 August, 2020

\begin{abstract}
The Taguchi experimental design is an experimental design to get the quality of an object by providing the best design at the procurement stage. In this case, the Taguchi design was applied to reduce the contents of lignin from rice straw, where lignin is one of the rice straw components that useless which must be reduced or eliminated. Rice straw is composed of lignin, cellulose and hemicellulose. The existence of lignin components that become a protective wall will inhibit the activity of cellulose, and hemicellulose for further processing to produce some fermented products such as bio-gas, bio-ethanol, bio-plastics, and others. The process of decreasing lignin content from rice straw is done in ozonolysis. In this study, Taguchi's experimental design analysis was using the application of MINITAB 14 which used for statistical calculation and create level setting in a tabular form of arrays called orthogonal arrays. The orthogonal array matrix used is L9 $\left(3^{3}\right)$ which states that the process was conducted 9 times with variations of 3 factors and 3 levels. The factors that influence the decrease in lignin levels include sample size, ozone flow rate, and contact time. The results showed that the smallest lignin content was carried out at 80 mesh sample size, the ozone flow rate of $3 \mathrm{~L}$ / Min, and contact time for 10 minutes.
\end{abstract}

\section{Introduction}

Straw is one of the paddy plants in the form of stems and leaves. Rice straw is used as fertilizer when planting crops, and as an alternative fodder by farmers during the dry season because of the difficulty of obtaining green grass bait. Rice straw is a farming waste that is a problem for farmers, therefore farmers will usually burn dried rice straw (Pratiwi, Rahayu, \& Barliana, 2016).

The main composition in rice straw consists of a lignocellulose component of about $79 \%$ dry weight, $26 \%$ hemicellulose, $33 \%$ cellulose, $7 \%$ lignin, and $13 \%$ silica. Rice Straw has now been developed as an alternative to raw materials in the manufacture of bioethanol and biogas to overcome the scarcity of fossil fuels. The presence of lignin content that binds to the Lignocellulose component will make it difficult to convert cellulose into simple sugars from rice straw. Cellulose is a component widely used as a raw material for the fermented products such as bio-ethanol and bio-gas, therefore lignin content of straw rice should be reduced or released (Novia, Windarti, \& Rosmawati, 2014). 
To reduce lignin levels more effectively and quality it is necessary to have an appropriate variable setting on the delignification process parameters. One of the most usable methods in quality control is the Taguchi method. The Taguchi method is a design to improve product quality and process in engineering so the use of resources will be more effective and efficient (Telaumbanua et al., 2013).

The purpose of this research is to analyze the appropriate process parameters with the Taguchi method to reduce the content of lignin from rice straw done by ozonolysis. Kappa numbers are chemical tests of rice straw samples to determine the degree of delignification. The testing of kappa numbers indicates lignin content. The test is based on the reaction with potassium permanganate $\left(\mathrm{KMnO}_{4}\right)$. From this research, it is expected to get a variable arrangement of the factors that influence in decreasing the lignin content of rice straw effectively through the Taguchi experimental design. The experimental design of Taguchi is one of the statistical methods used to improve and perform quality improvements so as to provide optimal research results (Andika, 2017).

There are several objectives by applying the Taguchi experimental design to this study:

a. Determine the variables that affect the process

b. Determine the influential variable $X$ set so that $Y$ output always approaches the intended normal value

c. Determine where the value of the influential variable $X$ must be adjusted so that the variability in $Y$ output can be as small as possible

d. Determine where the value of the influential variable $X$ must be regulated so that the influence of the uncontrolled variable $Z$ can be minimized.

With reduced levels of lignin from rice straw, it will be easier to process the conversion of cellulose and hemicellulose as a raw material in the development of alternative fuels.

\section{Literature Review}

Lignin is an arrangement of phenylpropane molecules composed of fibrous polymeric compounds in an amorphous state, and serves as a protective layer of lignocellulosic components and binds to hemicellulose and cellulose. Lignin does not belong to the carbohydrate group even though it is composed of carbon, hydrogen, and oxide because lignin is inside the cell wall and between cells (Bahri, 2017). Lignin fills the space within the cell wall between cellulose, hemicellulose, and pectin. Lignin is one of the main parts of water transportation in stem plants. The hydrophilic nature of plant cell wall polysaccharides makes it permeable to water. Whereas lignin has hydrophobic properties (Setiati, Wahyuningrum, Siregar, \& Marhaendrajana, 2016) which is insoluble in water, and strong mineral acids, soluble only with organic solvents, and dilute alkaline solutions (Kurnia Dewi, Wijaya Wirson, \& Dw Simaremare, 2011). Increased age of plants will increase the content of lignin on plant cell walls and provide a sturdy nature for plants (Setiarto, 2016).

Decreased lignin content is usually done in a variety of ways, namely: physically, biologically and ozonolysis. Decreased content of lignin or delignification by Ozonolysis is the most effective way to reduce the content of lignin by $16 \%$ and does not produce harmful waste to the environment. In 2012 it has been conducted a study on the reduction of lignin content by Novita et al. Their research aims to reduce the content of lignin on oil palm empty fruit bunches using ozonolysis method. The optimal delignification of their research is at a rate of oxygen flow 2 liters/minute and a 10 minute contact time resulting in decreased lignin content of 39.7 percent. 
Ozone is easily oxidized and reacts to lignin because ozone is a strong electrophilic (Novita et al., 2012).

\section{Research Methodology}

Research methodology is generally used by researchers in the field of information systems (Goundar, 2012). This study applies the delignification process with ozonolysis pre-treatment to reduce lignin levels from rice straw. The main raw material is rice straw obtained from agricultural land in the Musi 2 area of Palembang. After the delignification process, a Kappa number test is performed to obtain the value of lignin content from rice straw.

\subsection{Research stages}

\subsubsection{Determination of research variables}

The variables determined in this study are the factors that influence the reduction of lignin content from rice straw by using the sample weight as a fixed variable of 10 grams, including:

a. Response variable

Lignin contents

b. Control and Noise Factors

The control factor is the main factor that can be set the value or parameters that we control and the factors under study influence on the response. The setting of the selected level aims to minimize the effect of product response to noise factors (Putra \& Tontowi, 2019). While the noise factor is a factor that cannot be adjusted in value, although it can be regulated but it requires a high cost.

The Factors that considered in this study are:

a. Sample size (A)

The sample sizes used are: 40, 60 and 80 mesh

b. Ozone flow rate $(\mathrm{B})$

The level of the ozon flow rate carried out include: 3,4 and $5 \mathrm{~L} / \mathrm{min}$

c. Retention time $(\mathrm{C})$

The ozonolysis processing time or retention time is set at the level: 6,8 , and 10 minutes for each sample.

Table 1. Levels of Control Factors

\begin{tabular}{|c|c|c|c|c|}
\hline \multirow{2}{*}{$\begin{array}{c}\text { CONTROL } \\
\text { FACTOR }\end{array}$} & \multicolumn{3}{|c|}{ LEVEL } & \multirow[t]{2}{*}{ UNIT } \\
\hline & 1 & 2 & 3 & \\
\hline A & 40 & 60 & 80 & Mesh \\
\hline$B$ & 3 & 4 & 5 & $\mathrm{~L} /$ minute \\
\hline C & 6 & 8 & 10 & minute \\
\hline
\end{tabular}

\subsubsection{Orthogonal Array Selection}

An orthogonal array is a matrix in which elements are organized by row and column. Columns are factors that can be changed in the experiment, while the rows are level controlled. Arrays are called orthogonal because the level of factors is balanced and can be separated from the influence of other factors in the experiment. So orthogonal composition is a balanced matrix between factors and levels so that the influence of factors or levels does not mix with the influence of other factors (Efmi, Hari Adianto, \& Zaini, 2015). 
An orthogonal array is symbolized as follows:

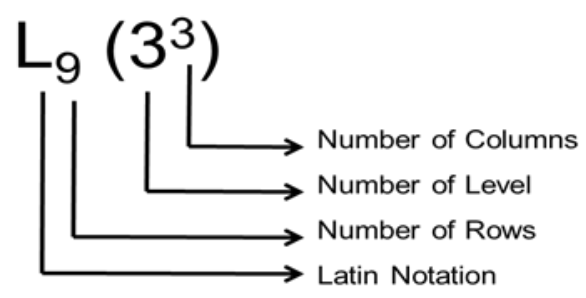

Figure 1. Orthogonal Array Notation

Orthogonal array $L_{9}\left(3^{3}\right)$ is interpreted as an orthogonal array that has 3 factors with 3 levels and the experiment is conducted 9 times. Then the selected orthogonal array is arranged in a matrix-like in table 2 below.

Table 2. Orthogonal Array Matrix $\mathrm{L}_{9}\left(3^{3}\right)$

\begin{tabular}{cccc}
\multirow{2}{*}{ EXPERIMENT } & \multicolumn{3}{c}{ LEVEL } \\
\cline { 2 - 4 } & A & B & C \\
\hline 1 & 1 & 1 & 1 \\
2 & 1 & 2 & 2 \\
3 & 1 & 3 & 3 \\
4 & 2 & 1 & 2 \\
5 & 2 & 2 & 3 \\
6 & 2 & 3 & 1 \\
7 & 3 & 1 & 3 \\
8 & 3 & 2 & 1 \\
9 & 3 & 3 & 2
\end{tabular}

\subsection{Data Analysis} 2019)

The data obtained are then processed and analyzed, among others: (Putra \& Tontowi,

a. Analysis of Variance (ANOVA)

Calculate the average

b. Calculating SNR

$$
\mu_{i}=\left[\frac{1}{n} \sum_{i=1}^{n} y_{i}\right]
$$

In reducing lignin levels, Signal to Noise Ratio (SNR) shows the smaller the better (Smaller the better)

$$
S N R_{s t b}=-10 \log \left[\frac{1}{n} \sum_{i=1}^{n} y_{i}^{2}\right]
$$

\subsection{Experiments}

\subsubsection{Preparation of raw materials}

Rice straw from agricultural land is first dried with the help of sunlight for 7 days, then chopped with a size of approximately $2 \mathrm{~cm}$, then dried in the oven for approximately 1 hour at a temperature of $80^{\circ} \mathrm{C}$. Dry rice straw is then ground and sieved according to the sample size 
studied, 40, 60, and 80 mesh. The sample size can affect porosity which then influences the contact of the delignificator.

Rice straw samples were analyzed for lignin content initially using the kappa method. To calculate Kappa numbers using the formula:(Baharuddin, Sappewali, Karisma, \& Fitriyani, 2016)

Where :

$$
K=(b-a) / w
$$

$\mathrm{K}=$ Kappa number

$\mathrm{b}=$ volume of titrant to a blank $(\mathrm{ml})$

$\mathrm{a}=$ volume of titrant to sample $(\mathrm{ml})$

$\mathrm{w}=$ sample weight (gram)

By Freudenberg, the Kappa value is multiplied by a factor of 0.147 to get the contents of lignin:

$$
\text { Lignin level }=\mathrm{K} \times 0.147
$$

Table 3. The Initial Lignin Contents of Rice Straw

\begin{tabular}{cc} 
SIZE (Mesh) & LIGNIN (\%) \\
\hline 40 & 1,615 \\
60 & 3,323 \\
80 & 4,263
\end{tabular}

\subsubsection{Ozonolysis delignification process}

Decreased lignin content is done in ozonolysis. Sample as much as 10 grams of straw rice is inserted into the ozonation tube as shown in Figure 1. Experiments according to such settings on the orthogonal array matrix $L_{9}\left(3^{3}\right)$.

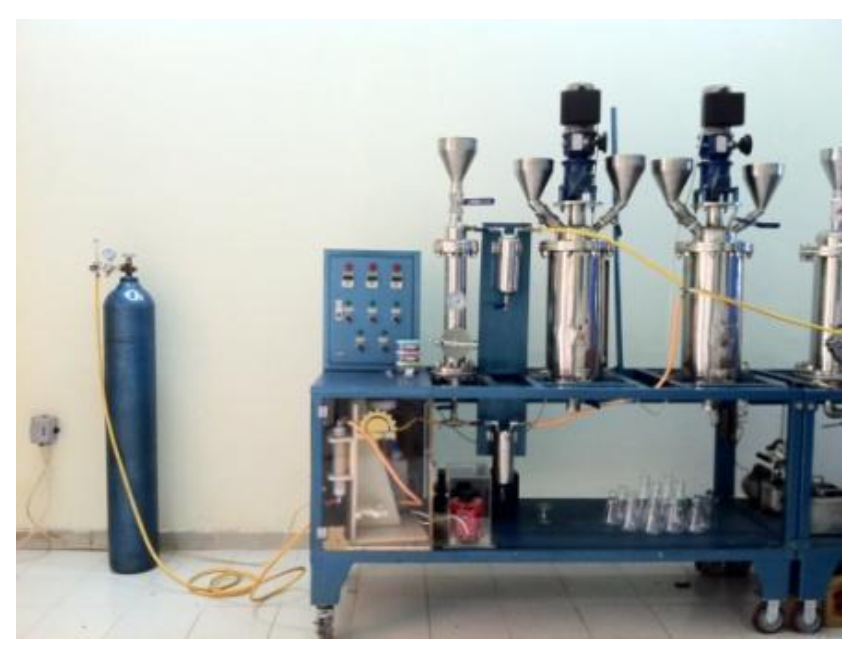

Figure 2. A Set of Ozonolysis Devices

Ozonolysis is a compound degradation method using ozone $(\mathrm{O} 3)$, in which the disconnection of bonds between $C=C$ to produce bonds duplicate $C=O$. The result of degradation depends on the type of bond oxidized dual and treatment conditions. As is ozone 
(O3), there is a breaking of the bonds between $\pi$ in alkenes resulting in 2 new $\mathrm{C}=\mathrm{O}$ bonds. Ozone can react with organic compounds either directly or indirectly through decomposition and formation of hydroxyl radicals or oxidation from organic species that might occur through a combination of reactions with ozone molecules and reactions with radical hydroxyl (Bhernama, 2017). Ozone is a strong oxidizing agent that can oxidize lignin from rice straw in acidic conditions. This is due to the excess of ozone compounds which have electrons and are acidic. The lignin ozonolysis reaction will produce an acetate group from the rice straw lignocellulose group. After passing through the process of ozonolysis, rice straw which has been reduced in lignin levels will be washed to neutral pH using distilled water.

Samples that have passed the ozonolysis process are then dried for 1 hour at $100^{\circ} \mathrm{C}$. The sample was then re-tested for its lignin levels using the Kappa Method.

\section{Results and Discussion}

Decreased rice straw lignin content is done by utilizing ozone which is a strong oxidizing substance and can oxidize lignin in acidic conditions. The process of reducing the content of lignin begins with the process of reducing rice straw and sifted into three sizes variations i.e. 40 mesh, 60 mesh, and 80 mesh. Reduce the size of straw rice aims to expand the contact surface where the smaller the particle size, it will be easier to absorb substances from additional materials (Gunam \& Wartini, 2011).

The next process is a sample of 10 grams of rice straw put into ozonolysis tubes. At this stage, ozone compounds flowed according to the ozone flow control control in table 1. In this process, the ozone compound will break down and eliminate the lignin content of rice straw. The ozonolysis process was carried out 9 times under the set level in the orthogonal array and repeated experiments 3 times, so the total number of experiments was 27 times. The 3 times repetition is meant to minimize errors and getting more precise trial data.

Before and after the ozonolysis process, lignin levels were tested for rice straw using the Kappa Method. The results of testing the levels of lignin after the ozonolysis process of rice straw can be seen in table 4 below.

Table 4. Test Results for Lignin Levels After Ozonolysis

\begin{tabular}{cccccc}
\multirow{2}{*}{ EXPERIMENT } & \multicolumn{3}{c}{ LIGNIN (\%) } & MEAN & SNR \\
\cline { 2 - 4 } & L1 & L2 & L3 & & \\
\hline 1 & 0,18 & 0,17 & 0,17 & 0,173 & 15,219 \\
2 & 0,17 & 0,16 & 0,16 & 0,163 & 15,735 \\
3 & 0,15 & 0,15 & 0,16 & 0,153 & 16,283 \\
4 & 0,21 & 0,19 & 0,21 & 0,203 & 13,826 \\
5 & 0,19 & 0,20 & 0,20 & 0,196 & 14,123 \\
6 & 0,18 & 0,18 & 0,17 & 0,176 & 15,054 \\
7 & 0,29 & 0,28 & 0,28 & 0,283 & 10,953 \\
8 & 0,26 & 0,25 & 0,26 & 0,256 & 11,811 \\
9 & 0,21 & 0,22 & 0,21 & 0,213 & 13,417
\end{tabular}

The data from Table 4 is then analyzed statistically using ANOVA and SNR smaller is better. ANOVA (Analysis of Variance) is a statistical analysis method that is used to test differences in the average data of more than two groups of factors. Signal to noise ratio is done for measure the level of sensitivity of the quality of each factor that is controlled for the influence of factors that are 
not controlled (Aprilyanti \& Suryani, 2020). Selection of SNR quality smaller is better states that the value of lignin content of rice straw the smaller the better. Following are the ANOVA data analysis results through MINITAB 14 in table 5 below.

Table 5. Analysis of Variance

\begin{tabular}{ccccccc} 
SOURCE & DF & SEQ SS & ADJ SS & ADJ MS & F & P \\
\hline SAMPLE SIZE & 2 & 20,8147 & 20,8147 & 10,4073 & 106,30 & 0,009 \\
OZONE FLOW RATE & 2 & 3,9071 & 3,9071 & 1,9536 & 19,95 & 0,048 \\
RETENTION TIMES & 2 & 0,4349 & 0,4349 & 0,2174 & 2,22 & 0,310 \\
RESIDUAL ERROR & $\mathbf{2}$ & $\mathbf{0 , 1 9 5 8}$ & $\mathbf{0 , 1 9 5 8}$ & $\mathbf{0 , 0 9 7 9}$ & & \\
TOTAL & $\mathbf{8}$ & $\mathbf{2 5 , 3 5 2 5}$ & & & &
\end{tabular}

From the table above, it is shown the final result of the two way ANOVA test. We can find out how much influence the independent variable to the dependent variable. In this research, independent variable is the factors measured by the researcher (sample size, contact time and retention time) to determine the effect, with the dependent variable (the observed value of lignin levels). From the table 5, we can see the value of lignin content is influenced by sample size and contact time based on the significance value $<0.05$ i.e. $(0,000<0.05)$, which means the value obtained is valid.

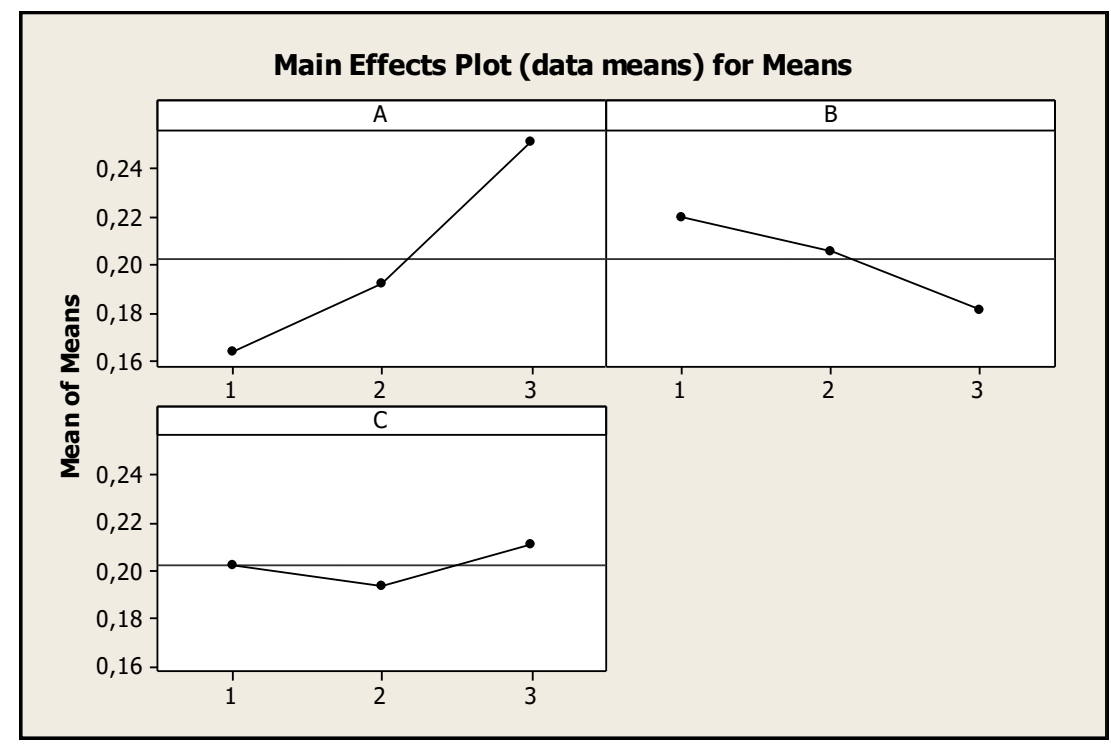

Figure 3. Main Effect Plot for Means

Table 6. SNR Smaller is Better

\begin{tabular}{cccc} 
LEVEL & SAMPLE SIZE & OZON FLOW RATE & RETENTION TIME \\
\hline 1 & 15,75 & 13,33 & 14,03 \\
2 & 14,33 & 13,89 & 14,33 \\
3 & 12,06 & 14,92 & 13,79 \\
Delta & $\mathbf{3 , 6 9}$ & $\mathbf{1 , 5 9}$ & $\mathbf{0 , 5 4}$ \\
Rank & $\mathbf{1}$ & $\mathbf{2}$ & $\mathbf{3}$
\end{tabular}




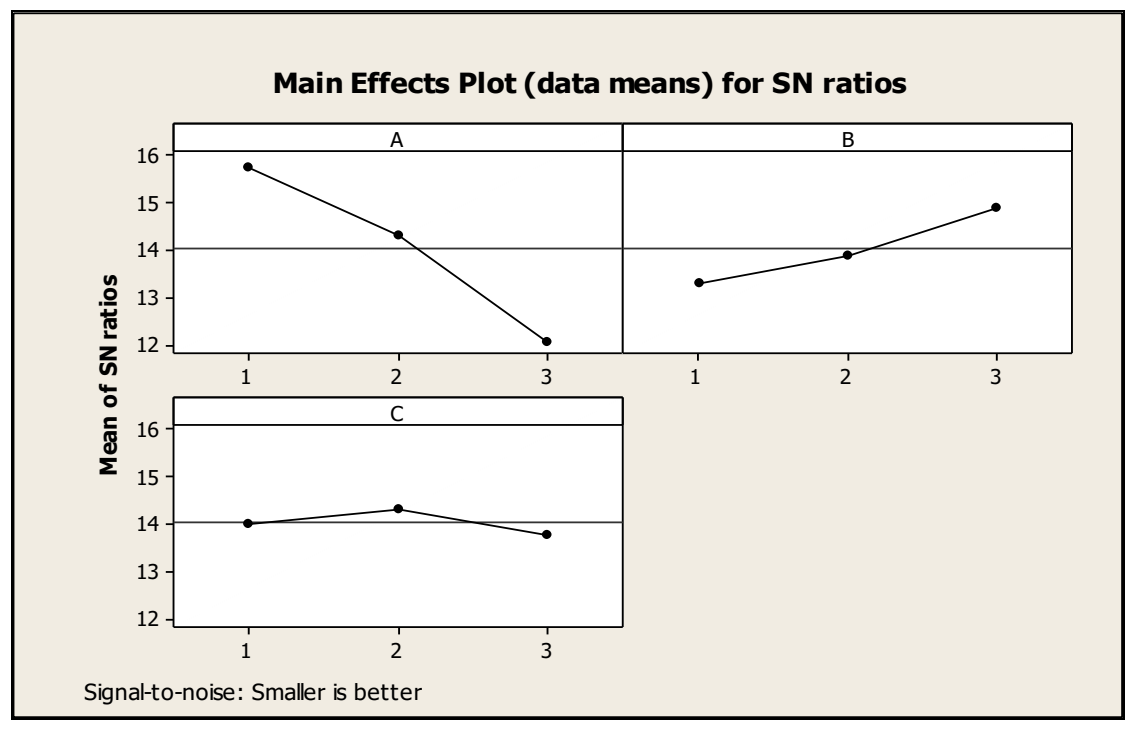

Figure 4. Main Effect Plot for SN Ratios

The flow rate and contact time have a significant effect. When the ozone flow rate is low and the retention time is not long then more concentrations of ozone will form. Conversely, if the flow rate and retention time are increased it will reduce the concentration of ozone that is formed. The process of reducing lignin content is better carried out at smaller ozone concentrations (Novia et al., 2014).

Determination of the smaller is better SNR quality on the reduction in lignin content of rice straw above shows that the smallest value in the sample size is at level 3 control factors, for the ozone flow rate the smallest SNR value is obtained at level 1 control factor, and the contact time has the smallest SNR value at the level 1 control factor. So based on Figure 3 above it can be concluded that to get the smallest lignin content, ozonolysis is carried out on 80 mesh of rice straw, the ozone flow rate of $3 \mathrm{~L} / \mathrm{min}$, and retention time for 10 minutes.

\section{Conclusion}

Reducing levels of rice straw lignin using the Taguchi experimental design is an effective and efficient way in designing a product. To get the smallest lignin content, the right process conditions are using a sample of 80 mesh of rice straw, ozone flow rate adjustment of $3 \mathrm{~L} / \mathrm{min}$ and contact time is carried out for 10 minutes. The smallest decrease in rice straw lignin levels using ozonolysis method is around $0.153 \%$.

\section{References}

Andika, Fendik (2017). Desain Eksperimen Taguchi dalam Optimasi Kuat Tekan Batu Bata. Jurnal IImiah Matematika, 1(6) , 14 -21.

Aprilyanti, S., \& Suryani, F. (2020). Penerapan Desain Eksperimen Taguhi untuk Meningkatkan Kualitas Produksi Batu Bata Dari Sekam Padi. J@TI UNDIP: Jurnal Teknik Industri, 15(2), 102-108.

Baharuddin, M., Sappewali, S., Karisma, K., \& Fitriyani, J. (2016). Produksi Bioetanol Dari Jerami 
Padi (Oryza Sativa L.) Dan Kulit Pohon Dao (Dracontamelon) Melalui Proses Sakarifikasi Dan Fermentasi Serentak (SFS). Chimica et Natura Acta, 4(1), 1. https://doi.org/10.24198/cna.v4.n1.10441

Bahri, S. (2017). Pembuatan Pulp dari Batang Pisang. Jurnal Teknologi Kimia Unimal, 4(2), 36. https://doi.org/10.29103/jtku.v4i2.72

Bhernama, B. G. (2017). Degradasi Zat Warna Malachite Green Secara Ozonolisis Dengan Penambahan Katalis $\mathrm{TiO} 2$ anatase dan ZnO. Elkawnie, 3(1), 1-10. https://doi.org/10.22373/ekw.v3i1.535

Efmi, A., Hari Adianto, R., \& Zaini, E. (2015). Usulan Perbaikan Kualitas Kuat Tekan Produk Bata Beton Paving Block Dengan Tambahan Trass Menggunakan Metode Taguchi. Jurnal Online Institut Teknologi Nasional Oktober.

Goundar, S. (2012). Research methodology and research questions. 3, 84-193.

Gunam, I. B. W. ; A., \& Wartini. (2011). Delignifikasi Ampas Tebu Dengan Larutan Natrium Hidroksida Sebelum Proses Sakaraifikasi Secara Enzimatis Menggunakan Enzim Selulase Kasar Dari Aspergillus Niger. Jurnal Teknologi Indonesia, 34(January), 24-32.

Kurnia Dewi, T., Wijaya Wirson, P., \& Dw Simaremare, C. (2011). Pengaruh Waktu Perendaman, Penambahan Serat Dan Suhu Perebusan Terhadap Kualitas Kertas Hasil Daur Ulang Kertas Bekas. Jurnal Teknik Kimia, 17(5), 1-9.

Novia, Windarti, A., \& Rosmawati. (2014). Pembuatan Bioetanol dari Jerami Padi dengan Metode Ozonolisis - Simultaneous Saccharification and Fermentation ( SSF ). Jurnal Teknik Kimia, 20(3), 38-48.

Pratiwi, R., Rahayu, D., \& Barliana, M. I. (2016). Pemanfaatan Selulosa Dari Limbah Jerami Padi (Oryza sativa) Sebagai Bahan Bioplastik. Indonesian Journal of Pharmaceutical Science and Technology, 3(3), 83. https://doi.org/10.15416/ijpst.v3i3.9406

Putra, G., \& Tontowi, E. (2019). Analisis Ukuran Pori Biokomposit ( Sericin - Bioplastik ) pada Berbagai Suhu Pembekuan Awal dengan Metode Taguchi. Jurnal Teknik Industri TRISAKTI, 9(3), 145-153.

Setiarto, R. H. B. (2016). Prospek Dan Potensi Pemanfaatan Lignoselulosa Jerami Padi Menjadi Kompos, Silase Dan Biogas Melalui Fermentasi Mikroba. Jurnal Selulosa, 3(02), 51-66. https://doi.org/10.25269/jsel.v3i02.44

Setiati, R., Wahyuningrum, D., Siregar, S., \& Marhaendrajana, T. (2016). Optimasi Pemisahan Lignin Ampas Tebu Dengan Menggunakan Natrium Hidroksida. ETHOS (Jurnal Penelitian Dan Pengabdian), (September 2018), 257. https://doi.org/10.29313/ethos.v0i0.1970

Telaumbanua, A., Siregar, K., Sinaga, T. S., Industri, D. T., Teknik, F., Utara, U. S., ... Usu, K. (2013). Analisis Pengendalian Kualitas Dengan Pendekatan Metode Taguchi Pada Pt Asahan Crumb Rubber. Jurnal Teknik Industri USU, 3(5), 1-7. 
This page is intentionally left blank. 